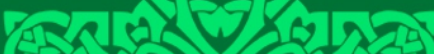
520030102 का 10 4 t

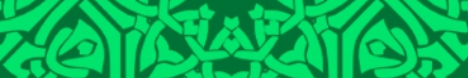
o 21205 रत्र 202 cos (2) 120

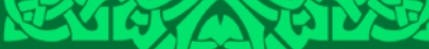
पis 4 कि

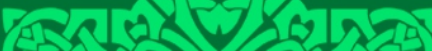
पित 1 (1) 0 (0)

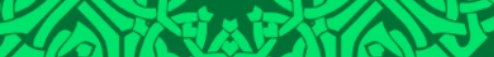
of 2505105 रन्तिए 0 cos 12 an

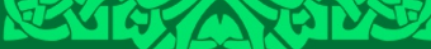
परत w कि Tat

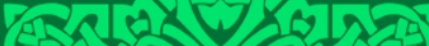
520100103 20 (1) 5 (5)
Sandra Dewi Dahlan, Mirotin Eka Wahyuningsih, Hasbi Assiddiqi, Edi Ardian, Rahmat Fajar The Role of Gossip as a Strategy to Reach Power in Tilik Short Movie

Hasaruddin, Sitti Mania, Ahmad Yani, Musyarif Tracking The Historical Development of Kedatuan Sawitto in South Sulawesi in The XVI-XVII Century

Abdul Muiz Amir, Sahiron Syamsuddin, Siswanto Masruri Dialectic Relationship Between The Qur'an and Hadith: The Interpretation of The Term "As-Sä'Ah" Using Critical Hermeneutic Analysis

Fachmi Alhadar, Safrudin Amin Covid-19 Poems as Cultural Response to Pandemic in Indonesia

Arini Indah Nihayaty, Bagong Suyanto, Sutinah A Study of Religious Symbols Attached to The Former Terrorist Convicts' Family as Seen in Social Interaction Wahyuddin, M. Abdul Hamid محاولات شوقي ضيف التجيديدية في تيسير النحو التعليمي

M. Napis Djuaeni, Hasyim Ashari نظام القافية ودوره في نشأَة المعاجم اللغوية العربية

Hasyim Haddade, Baso Pallawagau, Zaenal Abidin, Muhammad Zakir Husain التجديد في النحو: در اسة مذهب الخطيب الثربيني اللغوي في تفسيره السراج المنير

Nurhakki, Ahmad Sultra Rustan, Muhammad Taufiq Syam The Habituation of Tongkonan Communication as Adhesives for Religious Harmony in Toraja People

Nahdhiyah, Syahruni Junaid A Study of Al Qur'an towards Environmental Issues of Buginese ElongElong (Ecocritical Approach) UNIVERSITAS ISLAM NEGERI ALAUDDIN 


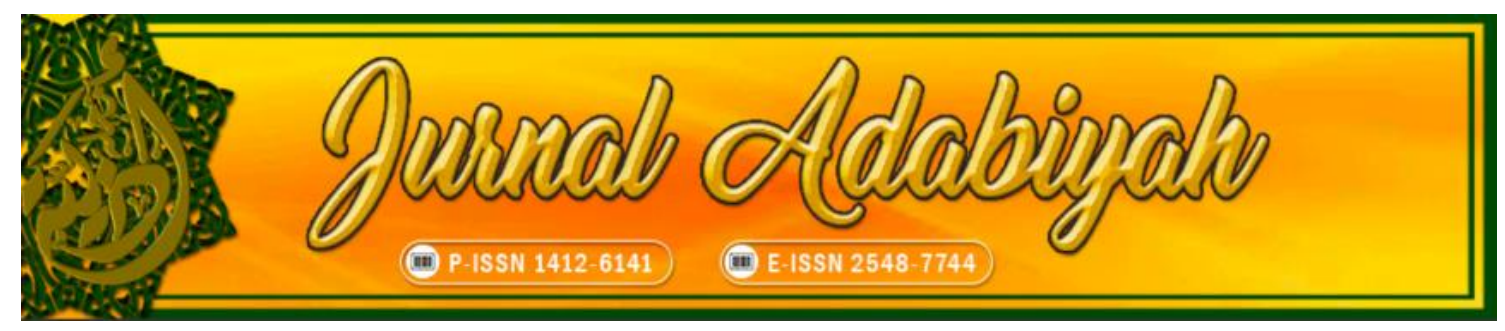

Theme: Humanities

VOLUME 21 NO. 1 JUNE 2021

\section{EDITOR-IN-CHIEF}

Nuri Emmiyati, Alauddin State Islamic University, Indonesia

\section{ASSOCIATE EDITOR}

Barsihannor, Alauddin State Islamic University, Indonesia

\section{INTERNATIONAL EDITORIAL BOARD}

Shamsi Ali, University of Northern California, United States

Miss Tiarne Jade Barratt, University of Sydney, Australia

Muhammad Widus Sempo, Universiti Sains Islam Malaysia, Malaysia

Salih Yousif Sharaf Mohamed, Al-Gazera University, Sudan

Aishah Waenaha Waemamah, Academy of Islamic and Arabic Studies Princess of Naradhiwas University

- Thailand, Thailand

\section{EXECUTIVE EDITOR}

Umar Thamrin, Alauddin State Islamic University, Indonesia

\section{MANAGING EDITOR}

Nasrum, Alauddin State Islamic University, Indonesia

\section{EDITORS}

Akbar Haseng, Institut Agama Islam Negeri Kendari, Indonesia Sardian Maharani Asnur, Alauddin State Islamic University, Indonesia Subehan Khalik Umar, Alauddin State Islamic University, Indonesia

Haniah, Alauddin State Islamic University, Indonesia

Andi Satrianingsih, Universitas Muhammadiyah Makassar, Indonesia

Awaluddin Syamsu, Universitas Muslim Indonesia

Muhammad Azwar, UIN Syarif Hidayatullah Jakarta, Indonesia

\section{ASSISTANT TO THE EDITORS}

Chusnul Chatimah Asmad, Alauddin State Islamic University, Indonesia

ENGLISH LANGUAGE ADVISOR

Rosmah Tami, Alauddin State Islamic University, Indonesia

Syahruni Junaid, Alauddin State Islamic University, Indonesia

\section{ARABIC LANGUAGE ADVISOR}

Muh. Saleh Syamsuri, Alauddin State Islamic University, Indonesia

Baso Pallawagau, Alauddin State Islamic University, Indonesia

\section{IT SUPPORT}

Taufiq Mathar, Alauddin State Islamic University, Indonesia

\section{COVER DESIGNER}

Nur Arifin 


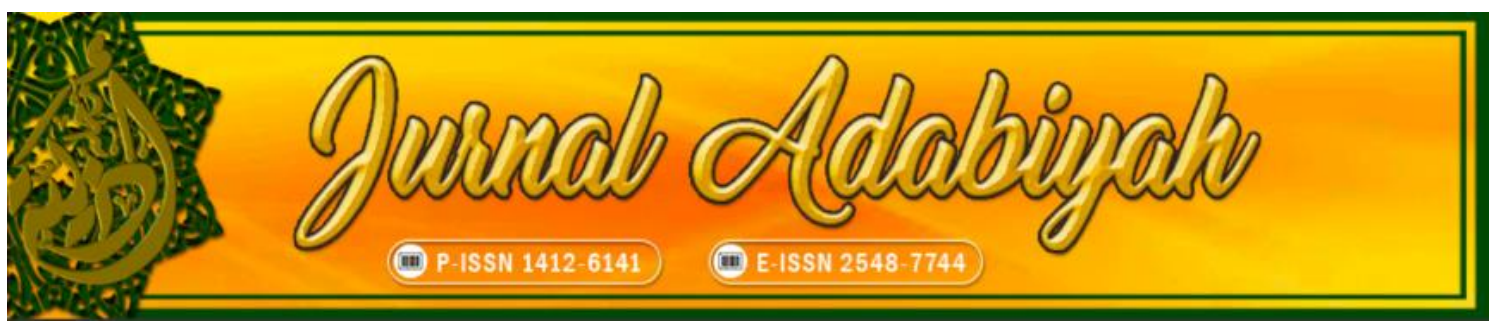

\section{Jurnal Adabiyah:}

This journal receives a national accreditation from Ministry of Research, Technology, and Higher Education Republic of Indonesia, Nomor 10/E/KPT/2019 on April 4, 2019 with the SINTA score: S2.

The Journal has been published by the Faculty of Adab and Humanity of Alauddin State Islamic University, Makassar, since 1997 and has been online since 2016 with the main themes on Humanities and Islamic Studies with the emphasis on interdisciplinary and intertextuality approach.

This journal are published twice a year, on June and December. The themes related to Islamic Studies are textual studies, scriptural traditions, Islamic law, and theology; and those related to Humanities are language, literature, history, and culture.

The journal of Humanities and Islamic Studies will provide the online collection of articles from 1997 up to now. The most updated information can be found on the website. 


\section{Table of Contents}

Besse Wahida, Khaerun Nisa Nuur, Ibnu Hajar Ansori

Tracing Entities of Arabic in The Qur'an

Sandra Dewi Dahlan, Mirotin Eka Wahyuningsih, Hasbi Assiddiqi,

Edi Ardian, Rahmat Fajar

The Role of Gossip as a Strategy to Reach Power in Tilik Short Movie

Hasaruddin, Sitti Mania, Ahmad Yani, Musyarif.

Tracking The Historical Development of Kedatuan Sawitto in South Sulawesi in The XVI-XVII Century

Abdul Muiz Amir, Sahiron Syamsuddin, Siswanto Masruri 57-81

Dialectic Relationship Between The Qur'an and Hadith: The Interpretation of The Term "As-Sā 'Ah" Using Critical Hermeneutic Analysis

Fachmi Alhadar, Safrudin Amin.

Covid-19 Poems as Cultural Response to Pandemic in Indonesia

Arini Indah Nihayaty, Bagong Suyanto, Sutinah

A Study of Religious Symbols Attached to The Former Terrorist Convicts' Family as Seen in Social Interaction

Wahyuddin, M. Abdul Hamid

محاولات شوقي ضيف التجبيليدية في تيسيل النحو الثعليهي

161-187

M. Napis Dj, Hasyim Ashari

نظام القافية ودوره في نشأة المعاجم اللغويا العربية

Hasyim Haddade, Baso Pallawagau, Zaenal Abidin,

Muhammad Zakir Husain

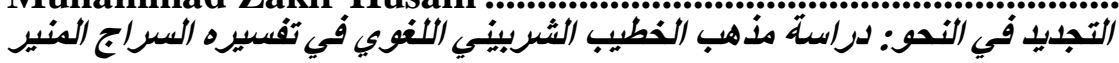

Nurhakki, Ahmad Sultra Rustan, Muhammad Taufiq Syam

The Habituation of Tongkonan Communication as Adhesives for Religious Harmony in Toraja People

Nahdhiyah, Syahruni Junaid

A Study of Al Qur'an towards Environmental Issues of Buginese ElongElong (Ecocritical Approach)

Jurnal Adabiyah Vol 21. Number 1/2021 


\title{
THE HABITUATION OF TONGKONAN COMMUNICATION AS ADHESIVES FOR RELIGIOUS HARMONY IN TORAJA PEOPLE
}

\author{
Nurhakki ${ }^{1}$, Ahmad Sultra Rustan ${ }^{2}$, Muhammad Taufiq Syam ${ }^{3}$ \\ Institut Agama Islam Negeri Parepare, Indonesia ${ }^{123}$ \\ Email: nurhakki@iainpare.ac.id ${ }^{1}$, ahmadsultrarustan@iainpare.ac.id², \\ muhtaufiqsyam@iainpare.ac.id ${ }^{3}$
}

\begin{abstract}
Religious differences within one family are often found in Toraja society. The four faces of God in one family are a symbol of a family living in harmony and upholding religious tolerance. This study examines how the habituation of communication in maintaining tolerance in building religious harmony in Toraja community is mediated through the existence of Tongkonan (traditional house of Toraja). This study used a qualitative descriptive method in the form of observations, interviews, and focus group discussion (FGD) at three locations which are the research objects, Lembang Madandan, Lembang Kaduaja and Lembang Tombang Langda. The results of this study indicate that a harmonious relationship among religions is a habitus that is built into the mental and cognitive domains that each individual is given freedom to choose religion, is respected (dianggak), is supported in worshiping (diangkak) which is the behavioral internalization of the three main attitudes; sianggak, sikalik, and siangkaran, with Tongkonan as the communication center for collective decision making, problem solving, and conflict resolution. The substance of this research can be used as a reference in realizing religious tolerance through the heritage of local traditions and culture.
\end{abstract}

Keywords: Habitus; Religious Harmony; Tongkonan; Toraja.

$$
\begin{aligned}
& \text { الملخص } \\
& \text { غالبًا ما توجد الاختلافات الدينية داخل عائلة منطقة واحدة في مجتمع توراجا } \\
& \text { وجوه رب الأربعة في شرفة واحدة هي تشبياه عائلي حي التناغم والتمسك } \\
& \text { بالتسـامح الديني. تبحث هذه الدراسة في كيفية تعويد التواصل في الحفاظ على } \\
& \text { التسـامح في بناء الانسجام الديني في مجتمع توراجا من خلال وجود تونغكونان } \\
& \text { (Tongkonan) } \\
& \text { الملاحظة والمقابلات ومجموعات التركيز مناقشة (FGD) في موقعين كانا موضع }
\end{aligned}
$$


بحث ، مقاطعة ماداندان في شمال توراجا وليمبانج كادواجا ،مقاطعة تانا

توراجا. نتائج هذه الدراسـة يوضح أن العلاقة المتناغمة بين المعتقدات هي عادة

مبنية في المجالات العقلية والمعرفية أن كل فرد يُمنح حرية اختيار الدين ،

ويحترم (يحترم) ، ويدعم في ممارسة العبادة (diangka) وهو الاستيعاب لسلوك هُك

المواقف الثلاثة الرئيسية : siangga و sikamalik و siangkaran ، مع في

Tongkonan

استخدام جوهر هذا البحث كأحد التوصيات.

Toraja; Tongkonan; الكلمات الدالة : التعود; الانسجام الديني

\begin{abstract}
Abstrak
Perbedaan agama dalam satu rumpun keluarga kerap ditemukan di masyarakat Toraja. Empat wajah Tuhan dalam satu beranda, merupakan analogi keluarga yang hidup harmonis dan memegang teguh toleransi beragama. Penelitian ini mengkaji bagaimana habituasi komunikasi dalam menjaga toleransi dalam membangun kerukunan beragama pada masyarakat Toraja yang dimediasi melalui keberadaan Tongkonan. Penelitian ini menggunakan metode deskriptif kualitatif berupa observasi, wawancara, dan focus group discussion (FGD) pada tiga lokasi yang menjadi objek penelitian, Lembang Madandan, Lembang Kaduaja dan Lembang Tombang Langda. Hasil penelitian ini menujukkan hubungan rukun antar keyakinan merupakan habitus yang dibangun dalam ranah mental dan kognitif bahwa setiap individu diberi kebebasan untuk memilih agama, dihargai (diangga'), didukung dalam menjalankan ibadah (diangka') yang merupakan rinternalisasi dari perilaku tiga sikap pokok; siangga', sikamalik', dan siangkaran, dengan Tongkonan sebagai pusat dalam pengambilan keputusan, pemecahan masalah, dan penyelesaian konflik. Substansi penelitian ini dapat dijadikan acuan dalam mewujudkan toleransi beragama melalui warisan tradisi dan budaya lokal.
\end{abstract}

Kata Kunci: Habituasi; Kerukunan Beragama; Tongkonan; Toraja

\title{
A. Introduction
}

Since the declaration of independence in Indonesian, this nation has revived the spirit of unity in diversity. The diversity of the population is certainly due to the 
religion, ethnicity, race, ethnicity, language, and culture. ${ }^{1}$ Living side by side in differences has been the dream and aspiration of the founder of the nation since Indonesia's independence. The philosophical formulation has been embodied in the Pancasila ideology with the slogan "Bhineka Tunggal Ika", bearing in mind that the struggle for independence has been achieved with the will and struggle with the tribes and races in Indonesia. In addition, preserving differences is an ideal in maintaining the treasures of the nation so that differences are respected and recognized in the sovereignty of the Unitary State of the Republic of Indonesia.

In Toraja people, religious differences in the family are not a barrier to maintaining harmony. From generation to generation the Toraja people are known as people who have strength because of unity and harmony that has been maintained since the colonial era. They have always had jargon which means unity, for example the heroes fighting against colonialism with the jargon 'Topada tindo tomisa pangimpi (together in sleeping with one dream), ${ }^{2}$ which means fighting together with one determination and purpose. Another well-known motto is misa' kaada diputuo pantan kaada dipumate'(one word we win, each one or another makes us die) ${ }^{3}$.

The people of Toraja are divided into two districts, namely North Toraja with the capital of Makale Regency and Tana Toraja Regency with the capital of Rantepao Regency. The areas bordering Enrekang and Pinrang Regencies in the south, Luwu and Mamuju Districts in the north, Polmas Regency in the west and Luwu Regency in the east. Before becoming a regency, it was given the name Tondok Lepongan Bulan Tana Matarik Allo", which means land or an area whose government is round like the sun. ${ }^{4}$

In social life, there are often religious differences, both within a family and within the community. The early religion that began to be embraced was the belief in alu' todolo (indigenous belief) as the religion of the ancestors of the Toraja people. Islam began to develop in 1876, Christianity entered in 1908 and Catholicism in 1938.

In Toraja, the district of Madandan was the initial place for the spread of Islam in Toraja which was known as 'madandan ditulak tallu', which means Madandan was built on three pillars symbolizing three different religions in its area. ${ }^{5}$ The description of the symbols of these three different religions can be found through the existence of the pillars found in the Tongkonan traditional house.

Tongkonan comes from the word tongkon, which means sitting. Tongkonan means a place to sit, a house, a gathering place for large families to carry out

\footnotetext{
${ }^{1}$ Muhammad Amri, Risna Mosiba, and Saidna Zulfiqar Bin-Tahir, "Interreligious Tolerance in the Perception of Maluku Muslim Society," Jurnal Adabiyah 20, no. 1 (2020), https://doi.org/10.24252/jad.v17i120i1a8. p. 180

${ }^{2}$ Nurdin Baturante, Tongkonan Dan Kerukunan (Yogyakarta: Pustaka Alzikra, 2019).

${ }^{3}$ Baturante. p. 144.

${ }^{4}$ Baturante.p. 2.

${ }^{5}$ Baturante. h. 118-162.
} 
traditional ceremonies together. ${ }^{6}$ Toraja people, symbolize Tongkonan as mother, while the alang sura (rice barn) which is usually in front of Tongkonan is symbolized as father. The front of the Tongkonan are also lined with buffalo horns which is proof that in the Tongkonan family ritual ceremonies were held, both the death ceremony (Aluk Rambu Solok) and the wedding ceremony (Aluk Rambu Tukak). ${ }^{7}$

The shape of Tongkonan Toraja, although it has undergone a transformation from time to time along with its development, includes transformations of spatial structure, function, and use of materials, ${ }^{8}$ but it does not eliminate its original form. The original building is banua tongkonan with a boat-shaped roof, facing north and south with the structure of the building only consisting of wood and bamboo without using nails. ${ }^{9}$ The first tongkonan built was the Layuk Tongkonan.

Tongkonan is the traditional house of the Toraja people, which is the residence, customary power, and the development of the social and cultural life of the Toraja people. ${ }^{10}$ This definition shows that the function of Tongkonan is not only as a cultural identity of the Toraja people but also as a center of life in the social dynamics of the community. Efforts to maintain the social consensus of the Toraja people through the existence of the Tongkonan occur in the realm of habitus.

The concept of habitus is a theory expressed by Bourdieu which describes the realm of the dialectical relationship that occurs between cultural traditions and the existence of social space in society. ${ }^{11}$ Habitus exists in the individual's mind while the environment is outside the individual's mind, but both are interrelated and influence each other. Habitus is a mental or cognitive structure that is formed in a person in carrying out social interactions.

Habitus describes a series of tendencies that encourage social actors or actors to act and react in certain ways. Habitus is a product of history, as a legacy from the past which is influenced by existing the social structures. As a product of history, habitus creates individual and collective actions according to patterns generated by history. Habits acquired through life experiences and have a function, are then

\footnotetext{
${ }^{6}$ Ezra Tari, “Teologi Tongkonan: Berteologi Dalam Konteks Budaya Toraja," EPIGRAPHE: Jurnal Teologi Dan Pelayanan Kristiani 2, no. 2 (January 23, 2019): 93, https://doi.org/10.33991/epigraphe.v2i2.40. p. 95.

${ }^{7}$ Nursalam Nursalam, "Makna Sosial Tongkonan Dalam Kehidupan Masyarakat Tana Toraja," Equilibrium: Jurnal Pendidikan $\quad 5, \quad$ no. 1 (2019), https://doi.org/10.26618/equilibrium.v5i1.972.

p. 31 .

${ }^{8}$ Shandra Stephany, "Interior Tongkonan Di Tana Toraja Sulawesi Selatan," Dimensi Interior, Vol.7, No.1, Juni 2009: 28-397 (2009). p. 28-39.

${ }^{9}$ Baturante, Tongkonan Dan Kerukunan. p. 210.

${ }^{10}$ Marcelina Sanda Lebang Pakan, Maria Heny Pratiknjo, and Welly E Mamosey, "Rumah Adat 'Tongkonan' Orang Toraja Kabupaten Tana Toraja Propinsi Sulawesi Selatan," HOLISTIK, Journal of Social and Culturef Social and Culture XI, no. 22 (2018). p. 2.

${ }^{11}$ GEORGE DAN DOUGLAS J. GOODMAN RITZER, “Teori Sosiologi Modern,” Protein Science, 2007. p. 522
} 
internalized in themselves, to be used to feel, understand, realize and assess the social world. ${ }^{12}$ It is through these patterns that individuals produce their actions and also judge them or in other words, the habitus controls the thoughts and choices of individual actions.

Habitus is carried out through habituation and continuous socialization so that social reflexes to maintain harmony can occur without realizing it. ${ }^{13}$ Habitus is as a result or product of internalization of the social world structure which is manifested and obtained as a result of the length of position in social life, so that the habitus will vary, depending on where and how the individual's position is in social life. If someone who occupies the same position in the social world then he has a tendency towards the same habits. In this sense, habitus can also be a collective phenomenon.

Habitus produces is produced by social life. On the one hand the habitus is a structured structure. That habitus is a structure that structures social life. On the other hand the habitus is a structured structure in which position the habitus becomes a structure structured by the social world. In other words, Bourdieu explains habitus as a dialectic of internalization of externalities and externalization of internalities. ${ }^{14}$ Thus, on the one hand, habitus is created by practice or action; on the other hand, habitus is the result of actions which social life creates.

Habitus is simply proposing what people should think and what they should choose to do. In making choices, actors use in-depth considerations based on awareness, even though this decision-making process reflects the role of the habitus. Habitus provides principles upon which actors make choices and choose strategies to use in social life, actors act in a reasonable manner. They have a feeling in acting, there is a logic for what the actor acts, this is called Bourdieu's logic of action. ${ }^{15}$ Bourdieu's logic of action (practical logic) is different from rationality (formal logic). There is a concept of relationalism from Bourdieu which is used to lead individuals to recognize that the habitus is not a fixed, immutable structure, but is adapted by individuals not unaware but using it strategically who are constantly changing in the face of the conflicting situations in which they exist.

Therefore, based on the description of the cultural characteristics of Toraja people from the existence of Tongkonan in collaboration with habitus theory, this study discusses problems related to the form of habituation that occurs in Toraja society in responding to religious diversity in one family that have a Tongkonan.

\footnotetext{
${ }^{12}$ RITZER. p. 522.

${ }^{13}$ I Nyoman Yoga Segara, "Kampung Sindu: Jejak Islam Dan Situs Kerukunan Di Keramas, Gianyar, Bali," Jurnal Lektur Keagamaan 16, no. 2 (2018), https://doi.org/10.31291/j1k.v16i2.563. p. 315-346.

${ }^{14}$ RITZER, “Teori Sosiologi Modern.” p. 523.

${ }^{15}$ Paul Rabinow and Pierre Bourdieu, "Structures, Habitus, Practices," in Rethinking the Subject, 2018, https://doi.org/10.4324/9780429497643-2. p. 92.
} 


\section{B. Research Method}

This study used descriptive qualitative method. Data collection methods include primary literature, observation, focus group discussion, and interviews with the grand tour question (GTQ) strategy developed by Spradley, which is a strategy that encourages informants to 'keep talking' (ramble on and on) ${ }^{16}$ in describing verbally. about their views on research issues. The informant's statement becomes the unit of analysis described.

This research was conducted in three locations including: Lembang Madandan, in Rante Tayo District, Lembang Kaduaja in Gandang Batu Sillanan District and Lembang Tombang Langda in Sopai District. The three places are heterogeneous areas of religious adherents in one family who have lived from generation to generation in one Tongkonan. There are four categories of informants taken as a source of information, such as: religious leaders (Islam, Catholic, Protestant) adherents of religion and beliefs, government and religious counselor. The categories of informants can be seen as follows:

Table 1

The categories of informants

\begin{tabular}{|c|l|l|l|}
\hline No & \multicolumn{1}{|c|}{ Name } & \multicolumn{1}{|c|}{ Position } & \multicolumn{1}{c|}{ Address } \\
\hline 1 & Safruddin, SE & $\begin{array}{l}\text { Member of Toraja } \\
\text { Parliament and Leader of } \\
\text { Al Hidayah Islamic } \\
\text { Boarding School }\end{array}$ & $\begin{array}{l}\text { Lembang Kaduaja, } \\
\text { Tana Toraja Regency }\end{array}$ \\
\hline 2 & Marten Saronglangi & Catholic Priest & $\begin{array}{l}\text { Lembang Madandan, } \\
\text { Tana Toraja Regency }\end{array}$ \\
\hline 3 & $\begin{array}{l}\text { Benyamin Turu' } \\
\text { Padang }\end{array}$ & Protestant Priest & $\begin{array}{l}\text { Lembang Madandan, } \\
\text { Tana Toraja Regency }\end{array}$ \\
\hline 4 & $\begin{array}{l}\text { Yosepina } \\
\text { Rombelayuk }\end{array}$ & Protestant Priest & $\begin{array}{l}\text { Lembang Kaduaja, } \\
\text { Tana Toraja Regency }\end{array}$ \\
\hline 5 & Halimah & $\begin{array}{l}\text { Religious Counselor of } \\
\text { Muslim in Religion } \\
\text { Ministry }\end{array}$ & $\begin{array}{l}\text { Gandang Batu } \\
\text { Sillanan District, Tana } \\
\text { Toraja Regency }\end{array}$ \\
\hline 6 & Sampe Baralangi & Aluk Todolo Believers & $\begin{array}{l}\text { Sopai District, North } \\
\text { Toraj Regency }\end{array}$ \\
\hline 7 & Fransiska Sarong & Muallaf & Lembang Madandan, \\
\hline
\end{tabular}

${ }^{16}$ Nurul Ilmi Idrus, “Mana’ Dan Éanan: Tongkonan, Harta Tongkonan, Harta Warisan, Dan Kontribusi Ritual Di Masyarakat Toraja,” ETNOSIA : Jurnal Etnografi Indonesia 1, no. 2 (2017), https://doi.org/10.31947/etnosia.v1i2.1612. p. 5. 
The results of the interviews were then analyzed using a descriptive method to explain the symbolic meaning contained in a Tongkonan and the habituation of the community in carrying out a pattern of religious tolerance in a family in one Tongkonan.

\section{Results and Analysis}

\section{The Symbolic Meaning of Tongkonan}

Tongkonan in practice and community action through tongkonan is very constructive in building the religious harmony of the Toraja community. Tongkonan comes from the word tongkon which means to sit, which gets the suffix (an), ${ }^{17}$ as a description of the verb in Toraja society which means to sit together in large numbers or commonly called sitongkon. Thus, the use of the word Tongkonan is more symbolic as a situation of mutual interaction, the presence of a family of one Tongkonan. ${ }^{18}$ Tongkonan as the main element of a tondok (region) is a symbol of the class level of a family that is in the social space of society (silaukna). This illustrates that Tongkonan is not only seen as a physical building but also a manifestation of the socio-cultural class that exists in a village (sillanan). ${ }^{19}$

Tongkonan as a form or artifact consists of tongkonan land and banua tongkonan as a form of Torajan physical culture. Tongkonan land is a form of land that belongs to a family that has several functions, including a cultural center, a place to live, fostering family rules. ${ }^{20}$ Tongkonan land is not owned individually but jointly with families (collectively). Is an inheritance that is owned jointly by the family and their descendants. The assets are in the form of wet land, namely rice fields, palimbongan (gardens) and padang panglambaran tedong (buffalo breeding land). On the land area of the Tongkonan family, one family (clan) builds residential houses called banua (residential houses) ${ }^{21}$ as the Toraja traditional houses as buildings that are built together in the Tongkonan land area.

\footnotetext{
${ }^{17}$ Baturante, Tongkonan Dan Kerukunan. p. 223.

${ }^{18}$ Interview with Safruddin, SE. Member Toraja Regency Parliament and Leader of Al Hidayah Islamic Boarding School in Lembang Kaduaja, 21 January 2020.

${ }^{19}$ Imam Indratno et al., "SILAU'NA TONGKONAN SEBAGAI SEBUAH REALITAS TONDOK," ETHOS (Jurnal Penelitian Dan Pengabdian), 2016, https://doi.org/10.29313/ethos.v0i0.1694. h. 75-84.

${ }^{20}$ Interview with Marten Sarolangi. Catholic priest in Lembang Madandan, Rante Tayo District, 21 May 2019..

${ }^{21}$ Sam'un Mukramin and Lukman Ismail, "Social Meaning of Mangara Banua Tongkonan Ceremony in Toraja Society," SIMULACRA: JURNAL SOSIOLOGI 1, no. 1 (2018), https://doi.org/10.21107/sml.v1i1.4984. h. 57-64.
} 
Figure 1

Picture of Tongkonan

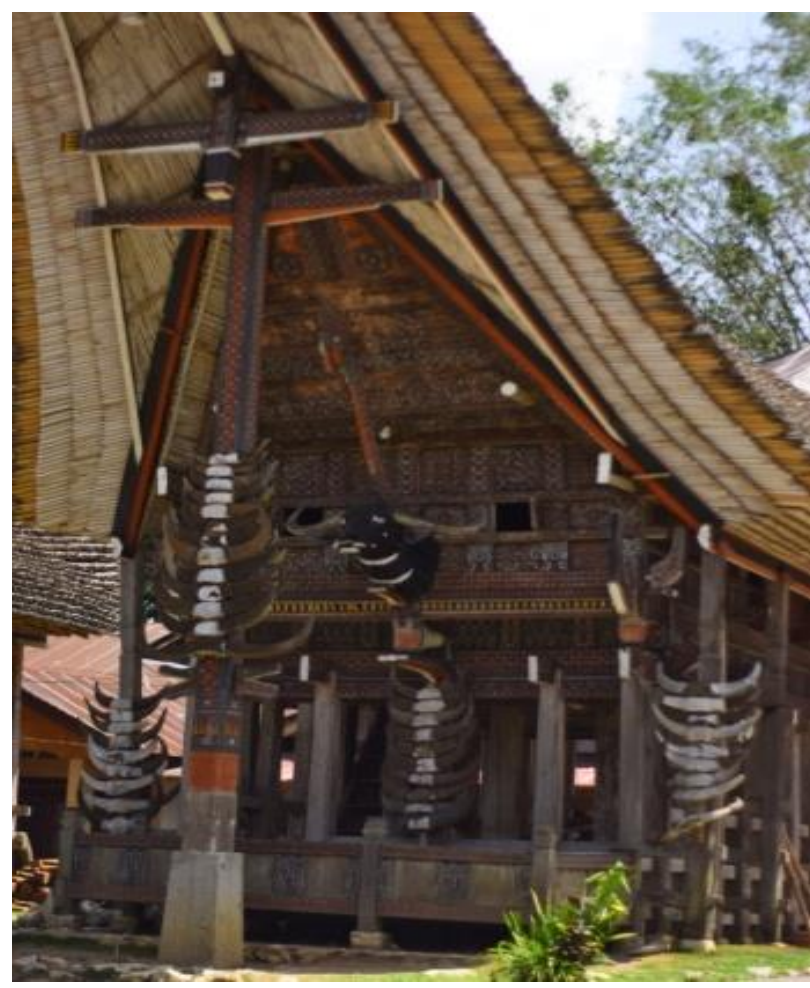

The basic form comes from the concept of Aluk Todolo, which sees the world of order (cosmos) in three parts, namely the upper world (ulunna langik), the middle world (kale banua), and the underworld (sulluk banua). ${ }^{22}$ The upper world (ulunna langik) is symbolized by the roof in the Tongkonan which is shaped like a boat. Second, the kale bola as a world meeting place between the Upper World and the Underworld. Kale Bola as a place for 'sitongkon' is given 'sali', which is a wooden structure that is understood as a form, the arrangement connotes harmony, mutual cooperation, and harmony. Kale Bola is a place to maintain balance, to maintain harmony in social life horizontally by maintaining a balance between orders and prohibitions (pemali). Third, sulluk banua, which symbolizes underworld was previously used as an area for buffalo or pig stalls.

${ }^{22}$ Interview with Marten Sarolangi. Catholic priest in Lembang Madandan, Rante Tayo District, 21 May 2019. 
Figure. 2

\section{Division of space in Tongkonan ${ }^{23}$}

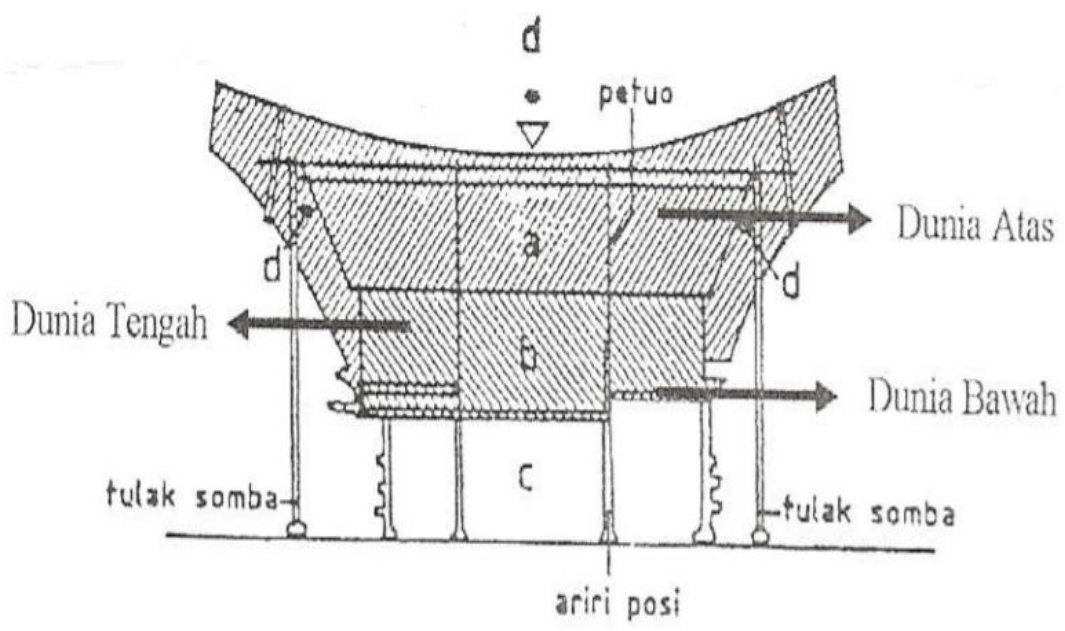

In the banua Tongkonan building, carving is also characterized by what is known as passurak. Passurak is a decoration attached to the Tongkonan with various colors which symbolizes the philosophy of the social form of life and human life of Toraja and symbolizes the position, role and function as well as the status of the tongkonan owner. There are approximately 150 types of passura which are grouped into four types, namely Pattedong, Pammanuk Londong, Pabbarre Allo, and Pasussuk. ${ }^{24}$ Carvings depicting symbols of objects and creatures in the life of the Toraja people and containing messages as symbols of the social status of the Toraja people are the philosophy of life of the Toraja people themselves.

Passurak Pabbarre allo which is a carving of a circle that resembles the sun and moon with its rays. Passura, which symbolizes the unity and unanimity of the Tondok Lepongan Bulan and Tana Matarik Allo, which is a function like the sun and the moon that can illuminate anyone with a round shape which means a unity which is expected to illuminate, guide, and bring glory to society. Passura Pammanuk Londong or carving resembling a rooster, where the rooster symbolizes honesty and justice, law and patriotism. There is a Toraja custom in the form of silondongan, which is pitting a rooster so that a rooster symbolizes the patriotism of a leader who

${ }^{23}$ Stephany, "Interior Tongkonan Di Tana Toraja Sulawesi Selatan." h. 28-39.
${ }^{24}$ Yudha Almerio Pratama Lebang, "Adat, Analisis Semiotika Simbol Kekuasaan Pada Rumah Layuk), Toraja (Tongkonan," in Prosiding Temu Ilmiah IPLBI (Program Studi Arsitektur, Fakultas Teknik, Universitas Malikussaleh, Lhokseumawe, 2017). 
upholds rules and norms and is fair in leading because the Toraja people basically believe that the crowing of a rooster is a determinant of time known as manarang usuka bongi (the arrival of evening) and ungkararoi malillin (the ending of darkness). ${ }^{25}$

Passurak pattedong carving buffalo. The buffalo (pattedong) is based on the belief of the Toraja people, symbolized as Garontok Eyanang or the basis of wealth so that the buffalo is a symbol of wealth, prosperity, and prosperity for the Toraja people. Passurak passusuk, namely passura 'which is in the form of a half hole made parallel and given a color symbolizing a struggle based on unity, kinship, mutual cooperation. ${ }^{26}$

Therefore, based on the meaning of the passurak (carving) contained in a Tongkonan has a function as a forum for various communication activities that take place in strengthening unity and harmony, including: a symbol or source of power as well as customary government that makes orders and pemali that governs the government and the social life that applies to the respective Tongkonan customary areas, the family history centers, the place for fostering family unity and unity to instill a sense of sianggak, sikamalik, and siangkaran, the symbol of family pride with an attractive and beautiful banua Tongkonan decorated in passurak, the activity center for the traditional ceremony of Rambu Tukak and Rambu Solok, a place for deliberation and solving family problems, kaada doolu banua (saying / saying something above the house) and all problems are resolved through Tongkonan.

The Toraja people, in their social relationships instill the value of habituation to their family members on how to operationalize the hierarchical identity model in an effort to harmonize between families through Tongkonan identities that are placed vertically as collective identities, while religious identity as personal-based social identities are placed horizontally. This shows that the social space in the family is a relationship of interaction between family members in Tongkonan who is directly tied to social activities, while religious matters are the rights and obligations of individuals in carrying out God's commands. The mutual respect for individual social identities in a family is a reflection of the form of habituation in the Toraja community, which consists of sianggak, sikamalik, and siangkaran habits.

\section{Habituation in Tongkonan}

a. Habit of Sianggak (Respecting for each other)

Sianggak comes from the word anggak with the prefix si which means mutual. Sianggak is giving each other prices in terms of important and valuable even though they are not valuable. An important value in communication because every object that

\footnotetext{
${ }^{25}$ Interview with Sampe Baralangi. Aluk Todolo Believers in Lembang Tombang Langda, Sopai District, North Toraja Regency, 25 January 2020.

${ }^{26}$ Interview with Sampe Baralangi. 25 January 2020.
} 
is assumed to have important value functions as a stimulus that greatly influences our thoughts and feelings in responding. A stimulus that is considered important to get priority is to give each other high apreciations.

In Tongkonan, Sianggak can be found on the Passurak Pabbarre Allo, the symbol of the moon and sun, which means that the moon and sun are different but they can complement each other and do not interfere with each other. appearance. If it is analogous to the different forms of belief that exist in the Toraja community, then this shows a mutual respect for every form of religious difference that exists in a Tongkonan family.

Sianggak (mutual respect) is the value of internalizing and organizing oneself individually and collectively so that it becomes a shared culture created from time to time in tongkonan. Strengthening the choice of religion is given a price for the ability to choose a religion according to beliefs.

Religious differences between siblings in a family can be accepted and appreciated because religion is an important thing for each individual to have. If there are religious differences in the family, Singgak can provide a sense of comfort in carrying out worship. One form of the implementation of Sianggak in families with different religions can be seen in the following interview results:

"I chose Islam when I was a teenager because I believed that Islam was the true religion. Parents and siblings accepted my decision, we stayed at the same house. Nothing stands in the way of my choice of religion. In carrying out my worship, I was given freedom, kept away from food that according to my religion was haram, because my siblings knew what I could and could not eat. During Ramadan, my Christian brother makes food for breaking the fast and sahur." ${ }^{27}$

The choice of different religions is not seen as a threat to separation physically or psychologically. Different religions still occupy the same house and tongkonan land. Intimacy and mingling in interactions are preserved on the basis of one tongkonan. Give each other flexibility with one another to carry out worship according to religion. The high prices are maintained with each other so that a sense of comfort over differences is maintained from time to time.

"I feel comfortable living next to a Muslim brother for life. The sound of the prayer to the mosque at dawn woke me up, so it was not too late to feed my pigs." 28

\footnotetext{
${ }^{27}$ Interview with Sampe Baralangi. 25 January 2020.

${ }^{28}$ Interview with Benyamin Turu' Padang. Protestant Priest in Lembang Madandan, Rante Tayo District, 21 May 2019.
} 
Kasianggaran are built in the context of affection and cognitive through the context of everyday life. Sianggak is a representation of relations through cultural practices of everyday life. Religion is an individual's important value and gives a price to each other's religions in life. Apart from belief, marriage is a factor of religious conversion in Toraja society. Interfaith marriages are carried out according to the traditional diparampo adak (come according to culture). As a ritual and customary recognition in the process of delivering the prospective groom, as well as the process of giving blessings to the partner. The marriage process is determined according to religion by the two partners without the intervention of the parents of both parties, without tug of war, without feeling of losing, winning, but giving price and recognition to the decision agreed upon by the couple to marry. Marriage as something busarungngu (smells good and fragrant), so it is rewarded with diparampo adak without debate, discussion, and family opposition, but the power and authority to decide the religious procession in the marriage process is fully given to the couple.

Sianggak in religious differences that has been built in interactions creates an understanding of sense making, both at the individual's internal perceptual level and at the level of intelligibility (cognitive intuitive). Sianggak at the perceptual level is the sensory activity of Toraja people to stimulate religious differences which is intensely responded to through sensory activities such as sight, hearing, touch, taste, and smell. Implementation of the level of intelligibility alert through communication practices that involve cognitive, emotional and intuition activities, as well as spiritual forces that will guide interactions both internally and externally.

In this habituation, a common understanding has been built on the importance of attitudes and behaviors to value of kasianggaran in that the difference is the human habit of Toraja as an internalization of cultural practices in tongkonan. Physical and psychological union is maintained based on kinship and puts a price on each other's choice of religion. Thus, sianggak habit is internalized and constructed continuously through tongkonan. Kasianggaran gave birth to a spirit of living together called sipori padang, sikambik aluk.

Sipori means an inseparable bunch, padang means the land area, sikambik means an unite and aluk is the religious teachings. So the meaning of this principle is to remain united and uphold the price of certain customary teachings or habits, whether there is a kasallangan (Islamic custom), there is a kasaranian (Christianity custom), or there is 'todolo (a custom from the teachings of aluk todolo).

Relational control that is built into tongkonan so that no one party or individual destroys relations between religions is known through the regulation of pemali (prohibition). One of them is the prohibition against damaging human relations which is called pemalinna aluk mellolo tau (prohibition concerning humans and humanity), among others: (1) pemali urromok sapean tabang (prohibition of restricting humans from facing safety ceremonies). (2) Pemali urromok panda 
dibolong (prohibited from restricting humans to face funeral ceremonies). (3) Pemali unnola tang lalanna (prohibition of doing inappropriate activities in social life).

\section{b. Habit of Sikamalikk (Longing for each other)}

Malik means longing. The use of sentences that are prefixed with si which means each other, so that sikamalikk means missing each other. Missing in psychological studies reflects a person's positive emotional atmosphere in the form of a strong desire for interpersonal affiliation with others in pleasure-based interactions. An emotional condition experienced when a relationship is limited by physical distance or proximity.

In Tongkonan, Sikamalik can be found in Passurak passusuk which is in the form of half holes made parallel and colorful. This symbol symbolizes a strong emotional connection bound to the great sense of unity and kinship that is owned and creates a desire to always maintain it.

Distance or physical separation for the Toraja ethnic group will give birth to feelings of sikamalik between one another. This assumption is of course based on the process of building relationships and escalation of relationships that have provided a comfortable climate of communication with each other when together both on verbal and non-verbal expressions on the basis of sianggak attitudes and behavior. Sikamalikk has been implemented by Toraja ethnicity through meetings at traditional ceremonies, either rambu tukak, rambu solok or mangrara ritual. In the traditional procession, all distant families are invited and must come during the ceremony which is held at the family's Tongkonan house.

Kasikamalikran (meetings) are a very urgent communication situation in the Toraja community, including meetings with families who have died even. On this basis, so that if there are family members who are non-Muslim, they are temporarily left in the Tongkonan house to wait for families who live outside Toraja to gather together to carry out the funeral ceremony for rambu solo, for Christians and followers of aluk todolo it is obliged to invite distant Muslim families. Also involved as ampu sara (the owner of the ceremony) during the ceremony procession and given the authority to take the role of carrying out the 'kasallangan' including preparing food for Muslim families, and vice versa.

Rambu solok ceremony (death) in Muslim families is called mattambun. ${ }^{29}$ All families of one tongkonan were invited and attended for the big family gathering. The procession is carried out for three days and three nights filled with recitation activities at night, and during the day receiving guests in barung-barung (house terrace). ${ }^{30}$ The whole family is present and mingles to meet at the mattambun ceremony even though

\footnotetext{
${ }^{29}$ Interview with Sampe Baralangi. 25 January 2020.

${ }^{30}$ Interview with Sampe Baralangi. 25 January 2020.
} 
they are non-Muslims. Likewise, when the celebration of religious holidays visits each other, such as Muslim families getting visits from non-Muslim families during Eid celebrations and vice versa.

Sikamalik is a depiction of belonging to one another. If they are separated, they will always try to create an atmosphere for the meeting. In addition to meetings through traditional ceremonies in Toraja for family gatherings they are also familiar with the activities of meeting all Toraja people in joint activities such as annual activities organized by the community such as Toraja Mamali and the government such as Lovely December Celebration. ${ }^{31}$

The feeling of sikamalikk is symbolized through the installation of a painting or passurak passusuk, which is a carving as a Tongkonan decoration in the form of a half hole made parallel and given a color symbolizing the feeling of sikamalikk, unity, kinship, mutual cooperation despite different beliefs. Tongkonan construction on kale banua as a center for family gatherings.

c. Habit of Siangkaran (Helping for each other)

Siangkaran (helping each other) is reflected in the climate of life of the Toraja people which is implemented through the context of life together. Siangkaran based on the word angkak which means to raise. Siangkaran is an attitude and behavior to mutually improve the quality of life and achieve the goals of mutual welfare and happiness.

The meaning of Siangkaran is illustrated in the Passurak Paktedong (carving of a buffalo) in Tongkonan which is symbolized as an effort made together in the family to obtain prosperity and prosperity for all family members, regardless of differences.

An attitude that is always oriented on the spirit to try to provide benefits in the relationship. Thus, Toraja people are always in a stable relationship despite religious differences. A stable relationship is a relationship that is predicted to last for a long time because each party in the relationship maintains it by providing mutual benefits, assistance, and support. The implementation of Siangkaran in responding the religious differences in society is illustrated in the following forms of social interaction that occurs in Toraja society in the following statement:

"When the church was inaugurated and there was a combined Christmas celebration at the church, I and the group of Majelis Taklim cooked for them and hopes they could focus on praying." 32

\footnotetext{
${ }^{31}$ Devi Roza Krisnandhi Kausar and Myra P. Gunawan, "Managing Heritage Tourism in Toraja: Strengthening Local Values and Improving Tourists' Experiences," Journal of Heritage Tourism 13, no. 6 (2018), https://doi.org/10.1080/1743873X.2017.1411356. h. 550-561.

${ }^{32}$ Interview with Halimah, Religious Counselor of Muslim in Religion Ministry in Gandang Batu Sillanan District, Toraja Regency, 19 January 2021.
} 
In terms of maintaining harmonious relations between religious adherents, sometimes it is also implemented in the form of each other's awareness to help each other and protect the property owned by others, so as to avoid the emergence of an attitude of fear and worry. In addition, the application of Sianggkaran can also be found in the involvement of adherents of other religions to participate in traditional events, without receiving discriminatory treatment. This is illustrated in the following statements:

"I never worried that my pigs would starve when I returned home in a few days, because our Muslim neighbors would help to look after and feed my pigs. ${ }^{\prime 33}$

"Since I became a Muslim, I have always been given the task of being a sallang cook (chef) when there are traditional parties." ${ }^{34}$

The three statements from the informants above are a form of implementation of siangkaran in relations between religious communities in Toraja. Helping each other in the sense of trying to provide assistance so that others can get out of the difficulties faced and contribute to meeting needs. Because the problems faced are considered to reduce the quality of life and condition of someone who experiences them, so that siangkaran becomes a better life solution. This is a reinforcement for the creation of harmony because in this principle, each other facilitates the achievement of life goals and provides support for each other to benefit in interfaith relations. Harmony between religions is well established on the basis of the implementation of siangkaran that religious differences are actually able to facilitate the achievement of physical needs, affection, completion of tasks, and obtaining resources.

"When I was a member of the Tana Toraja Regency parliament. The session to discuss the construction of the Jesus statue in Buntu Burake became a long discussion because of concerns about the emergence of discrimination prejudice against Muslims and non-Muslims in Tana Toraja district. Through the session I gave my opinion, development was continued as a tourist destination center that was attractive to tourists, both Muslim and nonMuslim, because it would help boost the economy of the community. Construction continued, and gave priority to Muslim traders to open stalls and sell Toraja accessories." 35

\footnotetext{
${ }^{33}$ Interview with Yosepina Rombelayuk, Protestant Priest in Lembang Kaduaju Gandang Batu Sillanan District, Toraja Regency, 19 January 2021.

${ }^{34}$ Interview with Fransiska Sarong Langi, a muallaf in Lembang Madandan, Rante Tayo District, 21 May 2019

${ }^{35}$ Interview with Safruddin, SE. 21 January 2020.
} 
The above statement shows the assumption that the building of Jesus has two functions, namely to become a symbol of pride for Christians and to provide a way for Muslims to increase their economic income.

The construction of the Bапиа Tongkonan which involved the whole family even though they were of different religions. Starting from the planning process, building construction (mengrimpun, massudduk, manglelleng, mangrimpun kaju, mangloppok, mangpabendan, mangriri posik, mangpalumbnag paatak makkemun rinding, makbaba lekok, mappetuo, malluntean, manggonok), and the inauguration (mappallin, sitaama, makgarugak, massuruk alang, manrimpun, untammui sukaran aluk, untammui lalanna tagari sangguyun, untammui lalanna kalimbuang booba, untammui lalanna tetean bori sola bulaan, mangrara banua) are the customary procession of tongkonan development which is subject to customary rules and involves the entire family including making material contributions to the construction of the Tongkonan. All elements of the family are given space to contribute in the form of money and energy to build. Thus the establishment of the Tongkonan becomes a symbol of pride for the attitude of siangkaran.

Tongkonan is a symbol of harmony as well as a center for family gatherings. It belongs at the same time to a common value and the center of cultural practice of sianggak, sikamalik, dan siangkaran. In order for the implementation of the three values to continue in tongkonan, the selection of elders known as peka amberan and peka indoran who are appointed as the father and mother of the Tongkonan is important. Peka amberan and peka indoran that are ditokko (legalized) as elders must be someone who has the credibility according to the passura symbol on the banua tongkonan. It must be someone who has a spirit of patriotism, is patient, honest, and fair to all (passurak manuk londong) has properties such as the sun and the moon which are the implementation of the symbol passurak pakbarre allo which has the spirit of maintaining family unity and is able to illuminate anyone regardless of religious differences. Having the ability to foster a spirit of helping each other to achieve prosperity which is symbolized by passurak pattedong. As long as the tongkonan custom is maintained in the Toraja people, inter-religious harmony is maintained.

\section{Conclusion}

Habituation that occurs in Toraja society generally leads to the internalization process between the local tradition of aluk todolo and the rituals of the new religions adopted by the people. The habituation process that focusing on the interaction between family members on the Tongkonan, proves that the series of images in the Tongkonan are symbols of an inseparable bond with the habituations of the Toraja people in responding to religious differences.

The habit of sianggak (respect), sikamalik (longing) and siangkaran (help) for each other are the concepts of the social behavior of the Toraja people in maintaining 
and preserving the ancestral traditions which aim to prevent conflicts and splits in a family which can be caused by there are differences in religion. The great enthusiasm to always maintain the existence of Tongkonan in the process of social interaction that occurs is believed to be able to maintain and maintain harmony between religious communities in Toraja society.

\section{E. Recomendation}

The research related to the habituation of communication that is built in a Tongkonan in order to maintain inter-religious harmony for the Toraja community which is discussed in this research, still needs to be developed further. Therefore, the researcher suggests and recommends to academics to conduct further studies and interpretations related to the meaning, function and role of symbols of cultural identity as a forum in building harmony and tolerance between religious communities.

\section{BIBLIOGRAPHY}

Amri, Muhammad, Risna Mosiba, and Saidna Zulfiqar Bin-Tahir. "Interreligious Tolerance in the Perception of Maluku Muslim Society." Jurnal Adabiyah 20, no. 1 (2020). https://doi.org/10.24252/jad.v17i120i1a8.

Baturante, Nurdin. Tongkonan Dan Kerukunan. Yogyakarta: Pustaka Alzikra, 2019.

Idrus, Nurul Ilmi. "Mana' Dan Éanan: Tongkonan, Harta Tongkonan, Harta Warisan, Dan Kontribusi Ritual Di Masyarakat Toraja." ETNOSIA : Jurnal Etnografi Indonesia 1, no. 2 (2017). https://doi.org/10.31947/etnosia.v1i2.1612.

Indratno, Imam, Sudaryono Sudaryono, Bakti Setiawan, and Kawik Sugiana. "SILAU'NA TONGKONAN SEBAGAI SEBUAH REALITAS TONDOK." ETHOS (Jurnal Penelitian Dan Pengabdian), 2016. https://doi.org/10.29313/ethos.v0i0.1694.

Kausar, Devi Roza Krisnandhi, and Myra P. Gunawan. "Managing Heritage Tourism in Toraja: Strengthening Local Values and Improving Tourists' Experiences." Journal of Heritage Tourism 13, no. 6 (2018). https://doi.org/10.1080/1743873X.2017.1411356.

Mukramin, Sam'un, and Lukman Ismail. "Social Meaning of Mangara Banua Tongkonan Ceremony in Toraja Society." SIMULACRA: JURNAL SOSIOLOGI 1, no. 1 (2018). https://doi.org/10.21107/sml.v1i1.4984. 
Nursalam, Nursalam. "Makna Sosial Tongkonan Dalam Kehidupan Masyarakat Tana Toraja." Equilibrium: Jurnal Pendidikan 5, no. 1 (2019). https://doi.org/10.26618/equilibrium.v5i1.972.

Pakan, Marcelina Sanda Lebang, Maria Heny Pratiknjo, and Welly E Mamosey. "Rumah Adat 'Tongkonan' Orang Toraja Kabupaten Tana Toraja Propinsi Sulawesi Selatan." HOLISTIK, Journal of Social and Culturef Social and Culture XI, no. 22 (2018).

Rabinow, Paul, and Pierre Bourdieu. "Structures, Habitus, Practices." In Rethinking the Subject, 2018. https://doi.org/10.4324/9780429497643-2.

RITZER, GEORGE DAN DOUGLAS J. GOODMAN. "Teori Sosiologi Modern." Protein Science, 2007.

Segara, I Nyoman Yoga. "Kampung Sindu: Jejak Islam Dan Situs Kerukunan Di Keramas, Gianyar, Bali.” Jurnal Lektur Keagamaan 16, no. 2 (2018). https://doi.org/10.31291/jlk.v16i2.563.

Stephany, Shandra. "Interior Tongkonan Di Tana Toraja Sulawesi Selatan.” Dimensi Interior, Vol.7, No.1, Juni 2009: 28-39 7 (2009).

Tari, Ezra. "Teologi Tongkonan: Berteologi Dalam Konteks Budaya Toraja." EPIGRAPHE: Jurnal Teologi Dan Pelayanan Kristiani 2, no. 2 (January 23, 2019): 93. https://doi.org/10.33991/epigraphe.v2i2.40.

Yudha Almerio Pratama Lebang. "Adat, Analisis Semiotika Simbol Kekuasaan Pada Rumah Layuk), Toraja (Tongkonan." In Prosiding Temu Ilmiah IPLBI. Program Studi Arsitektur, Fakultas Teknik, Universitas Malikussaleh, Lhokseumawe, 2017. 


\section{Guidelines}

\section{Submission of Article}

urnal Adabiyah welcomes the articles submission with the main themes on Humanities and Islamic Studies with the emphasis on interdisciplinary and intertextuality approach. Adabiyah is thematicly published twice in a year. ie the theme of the humanities in June and the Islamic Study in December.

Themes related to Islamic Studies are textual studies, scriptural traditions, Islamic law, and theology; and those related to Humanities are language, literature, history, and culture. This scholarly journal Guarantees that the editor decision based on the peer review results will not exceed 30 days from the paper submission date.

Authors are invited to read our archives; to find the relevant topics for the journal, and to submit complete unpublished scientific researches, which are not under review in any other conferences or academic journal.

\section{PUBLICATION ETHIC}

Publication Ethic and Malpractice Statement

Jurnal Adabiyah is a peer-reviewed journal, published twice a year by the Faculty of Adab and Humaniora, Alauddin State Islamic University of Makassar Indonesia. It is available online as open access sources as well as in print. This statement clarifies ethical behaviour of all parties involved in the act of publishing an article in this journal, including the author, the editor-in-chief, the Editorial Board, the reviewers, and the publisher. This statement is based on COPE's Best Practice Guidelines for Journal Editors.

Ethical Guideline for Journal Publication

The publication of an article in Jurnal Adabiyah, is an essential building block in the development of a coherent and respected network of knowledge. It is a direct reflection of the quality of the work of the authors and the institutions that support them. Peer-reviewed articles support and embody the scientific methods. It is therefore important to agree upon standards of expected ethical behavior for all parties involved in the act of publishing: the author, the editor, the reviewer, the publisher, and the society. As the publisher of Jurnal Adabiyah, the Faculty of Adab and Humaniora takes its duties of guardianship over all stages of publishing seriously and it recognizes its ethical and other responsibilities. The Faculty of Adab and Humaniora committed to ensuring that advertising, reprint or other commercial revenue has no impact or influence on editorial decisions.

\section{Publication Decisions}

The editors of Jurnal Adabiyah is responsible for deciding which articles submitted to the journal should be published. The validation of the work in question and its importance to researchers and readers must always drive such decisions. The editors may be guided by the policies of the journal's editorial board and constrained by such legal requirements as shall then be in force regarding libel, copyright infringement, and plagiarism. The editors may confer with other editors or reviewers in making their decisions.

\section{Plagiarism Screening}

It is basically author's duty to only submit a manuscript that is free from plagiarism and academically malpractices. The editor, however, will check all submitted papers through Turnitin.

\section{Fair Play}

An editor at any time evaluates manuscripts for their intellectual content without regard to race, gender, sexual orientation, religious belief, ethnic origin, citizenship, or political philosophy of the authors. 


\section{Confidentiality}

The editors and any editorial staff must not disclose any information about a submitted manuscript to anyone other than the corresponding author, reviewers, potential reviewers, other editorial advisers, and the publisher, as appropriate.

\section{Disclosure and Conflicts of Interest}

Unpublished materials disclosed in a submitted manuscript must not be used in editors' own research without the express written consent of the author.

\section{DUTIES OF AUTHORS}

\section{Reporting Standards}

Authors of reports of original research should present an accurate account of the work performed as well as an objective discussion of its significance. Underlying data should be represented accurately in the paper. A paper should contain sufficient detail and references to permit others to replicate the work. Fraudulent or knowingly inaccurate statements constitute unethical behaviour and are unacceptable.

\section{Originality and Plagiarism}

The authors should ensure that they have written entirely original works, and if the authors have used the work and/or words of others that this has been appropriately cited or quoted.

\section{Multiple, Redundant, or Concurrent Publication}

An author should not in general publish manuscripts describing essentially the same research in more than one journal or primary publication. Submitting the same manuscript to more than one journal concurrently constitutes unethical publishing behaviour and is unacceptable.

\section{Acknowledgement of Sources}

Proper acknowledgment of the work of others must always be given. Authors should cite publications that have been influential in determining the nature of the reported work.

\section{Authorship of the Paper}

Authorship should be limited to those who have made a significant contribution to the conception, design, execution, or interpretation of the reported research. All those who have made significant contributions should be listed as co-authors. Where there are others who have participated in certain substantive aspects of the research project, they should be acknowledged or listed as contributors. The corresponding author should ensure that all appropriate co-authors and no inappropriate co-authors are included on the paper, and that all co-authors have seen and approved the final version of the paper and have agreed to its submission for publication.

\section{Disclosure and Conflicts of Interest}

All authors should disclose in their manuscript any financial or other substantive conflict of interest that might be construed to influence the results or interpretation of their manuscript. All sources of financial support for the project should be disclosed.

\section{Fundamental errors in Published Works}

When an author discovers a significant error or inaccuracy in his/her own published work, it is the author's obligation to promptly notify the journal editor or publisher and cooperate with the editor to retract or correct the paper.

\section{PLAGIARISM}

It is basically author's duty to only submit a manuscript that is free from plagiarism and academically malpractices. The editor, however, will check all submitted papers through Turnitin. 


\section{AUTHOR GUIDELINES}

\section{Guidelines for online submission:}

1. Author should first register as Author to the website of Jurnal Adabiyah. Click the menu "register" to register as an author.

2. Once after the author is registered, please login to the website of Jurnal Adabiyah and submit the article through online submission (with the stat us of active submissions).

3. The article should follow the standard template of Jurnal Adabiyah provided in the website.

4. The citation and bibliography should follow the Turabian citation style.

5. Author is restricted not to send his/her article to another journal before having confirmation from the editorial team (approximately 4 weeks right after the article submitted).

6. Author should follow editorial decisions and recommendations related to the article completion. All reviews and assessements will be informed through online submission.

Article submitted to Jurnal Adabiyah editorial board must follow these guidelines:

1. Article should be based on the scientific research in the field humanities and Islamic studies;

2. Article must be an original work and has not been previously published;

3. Article should be written in Arabic or English languages;

4. Article must be typed in one-half spaced on A4-paper size;

5. Article's length is about $6,000-10,000$ words;

6. All submission must include a 150-250 word abstract;

7. Abstract should be written in 3 languages; Arabic, English, and Bahasa;

8. Full name(s) of the author(s) must be stated, along with his/her/their institution and complete address;

9. All submission should be in OpenOffice, Microsoft Word, RTF, or WordPerfect document file format;

10. Bibliographical reference must be noted in footnote and bibliography according to Jurnal Adabiyah style. In addition, it is suggested for author(s) to use reference manager tools such

\section{as MENDELEY or 7 otero}

When a source is cited for the first time, full information is provided: full name(s) of author(s), title of the source in italic, place of publication, publishing company, date of publication, and the precise page that is cited. For the following citations of the same source, list the author's last name, two or three words of the title, and the specific page number(s). The word ibid., op.cit., and loc.cit. are may not be used any more.

\section{Example in footnotes:}

${ }^{1}$ Mircea Eliade (ed.), The Encyclopedia of Religion, vol. 8 (New York: Simon and Schuster, 1995), h. 18.

${ }^{2}$ Norman Daniel, Islam and the West (Oxford: One World Publications, 1991), h. 190.

${ }^{3}$ Syeikh Ja'far Subhāni, Mafăhim Al-Qur'ān (Beirut: Mu'assasah Al-Tarīkh Al-'Arabī, 2010)., Juz 5, h. 231. 
${ }^{4}$ Syeikh Ja'far Subhānī, Mafāhim Al-Qur'ān, h. 8-9.

\section{Example in bibliography:}

Subhānī, Syeikh Ja'far. Mafăhim Al-Qur'ān. Beirut: Mu'assasah Al-Tarīkh Al-’Arabī, 2010.

Eliade, Mircea (ed.). The Encyclopedia of Religion, vol. 8. New York: Simon and Schuster, 1995.

Daniel, Norman. Islam and the West. Oxford: One World Publications, 1991.

Shihab, Muhammad Quraish. Sunnah-Syiah Bergandengan Tangan: Mungkinkah? Kajian Atas Konsep Ajaran Dan Pemikiran. Cet. III. Jakarta: Lentera Hati, 2007.

\section{Detail informations of the footnotes:}

1. Holy book

Al-Qur'ân, Al-Baqarah/2: 185.

Perjanjian Baru, Mrk. 2: 18.

2. Qur'anic translation

${ }^{1}$ Departemen Agama RI, al-Qur'an dan Terjemahannya (Jakarta: Darus Sunnah, 2005), h. 55.

3. Book

${ }^{1}$ Muḥammad 'Ajjaj al-Khațib, Ușl al-Hadith: 'Ulumuh wa Mușțalaḥ uh (Beirut: Dâr al-Fikr, 1989), h. 57.

4. Translation Books

${ }^{1}$ Toshihiko Izutsu, Relasi Tuhan dan Manusia: Pendekatan Semantik terhadap al-Qur'an, terj. Agus Fahri Husein dkk (Yogyakarta: Tiara Wacana, 2003), h. 14.

5. Voluminous book

${ }^{1}$ Muḥammad al-Ṭâhir b. 'Ashur, al-Tahrīir wa al-Tanwīr, Vol. 25 (Tunisia: Dâr al-Suhûn, 2009), h. 76.

${ }^{1}$ Muḥammad b. Ismā‘īl al-Bukharī, al-Jami‘ al-Ṣaḥịh, Vol. 2 (Beirut: Dar al-Kutub al-‘Ilmı́yah, 1999), h. 77.

6. Article in book

${ }^{1}$ Sahiron Syamsuddin, "Metode Intratekstualitas Muhammad Shahrur dalam Penafsiran al-Qur'an" dalam Abdul Mustaqim dan Sahiron Syamsuddin (eds.), Studi al-Qur'an Kontemporer: Wacana Baru Berbagai Metodologi Tafsir (Yogyakarta: Tiara Wacana, 2002), h. 139.

7. Article in encyclopaedia

${ }^{1}$ M. Th. Houtsma, "Kufr" dalam A. J. Wensinck, at al. (ed.), First Encyclopaedia of Islam, Vol. 6 (Leiden: E.J. Brill, 1987), h. 244.

8. Article in journal

${ }^{1}$ Muhammad Adlin Sila, "The Festivity of Maulid Nabi in Cikoang, South Sulawesi: Between Remembering and Exaggerating the Spirit of Prophet", Studia Islamika 8, no. 3 (2001): h. 9.

9. Article in mass media

${ }^{1}$ Masdar F. Mas'udi, "Hubungan Agama dan Negara”, Kompas, 7 Agustus 2002. 
10. Article in Internet

${ }^{1}$ Muhammad Shahrūr, "Reading the Religious Teks: a New Approach" dalam http://www.shahrour.org/25 Februari 2010/diakses 5 Juni 2010.

11. Thesis or dissertation

${ }^{1}$ Syahruddin Usman, "KinerjaGuru Penddikan Agama Islam pada SMAN dan SMKN Kota Makassar”, Disertasi (Makassar: PPs UIN Alauddin, 2010), h. 200.

\section{COPYRIGHT NOTICE}

Authors who publish with this journal agree to the following terms:

1) Authors retain copyright and grant the journal right of first publication with the work simultaneously licensed under a Creative Commons Attribution License that allows others to share the work with an acknowledgement of the work's authorship and initial publication in this journal.

2) Authors are able to enter into separate, additional contractual arrangements for the non-exclusive distribution of the journal's published version of the work (e.g., post it to an institutional repository or publish it in a book), with an acknowledgement of its initial publication in this journal.

3)Authors are permitted and encouraged to post their work online (e.g., in institutional repositories or on their website) prior to and during the submission process, as it can lead to productive exchanges, as well as earlier and greater citation of published work (See The Effect of Open Access). 